\title{
Pediatric Hematology/Oncology
}

National Cancer Institute

\section{Source}

National Cancer Institute. Pediatric Hematology/Oncology. NCI Thesaurus. Code C17844.

A medical specialty that focuses on diseases and disorders of the blood and bloodforming tissues in children. 